\title{
ARTYKUŁY
}

Klio. Czasopismo poświęcone dziejom Polski i powszechnym

PL ISSN 1643-8191, t. 28 (1)/2014, s. 129-151

(c) (1) $\odot$

DOI: http://dx.doi.org/10.12775/KLIO.2014.006

KRZYSZTOF TARKA

(Opole)

\section{Polityczne meandry emigracyjnego socjalisty. Kontakty Henryka Polowca z wywiadem PRL w latach 1952-1963}

$\mathrm{D}$ nia 27 kwietnia 1954 roku Centralny Komitet Zagraniczny Polskiej Partii Socjalistycznej przyjął jednomyślnie uchwałę o zawieszeniu Henryka Polowca w prawach członka partii i skierowaniu sprawy do sądu partyjnego $\mathrm{z}$ wnioskiem o wydalenie go z szeregów PPS. Powodem tak zdecydowanych działań miało być napisanie przez Polowca artykułu do „Narodowca”, pisma „szkalującego Polską Partię Socjalistyczną i jej linię polityczną" (wydawany w Lens dziennik sympatyzował ze Stanisławem Mikołajczykiem). W komunikacie opublikowanym na łamach „Robotnika” przypomniano, że już półtora roku wcześniej CKZ PPS nie zezwolił Polowcowi na umieszczanie artykułów w „obcej prasie”.

W rzeczywistości chodziło nie tyle o jeden artykuł - ten co najwyżej przelał przysłowiową czarę goryczy - ile o trwającą od kilku lat krytykę linii politycznej kierownictwa PPS. W inkryminowanym tekście na łamach

${ }^{1}$ Komunikat CKZ PPS, „Robotnik” 1954, nr 3, s. 5. 
„Narodowca” z 20 kwietnia 1954 roku Polowiec, nie wymieniając nazwisk, oskarżył emigracyjnych polityków o rozmaite „łajdactwa” i „czyny hańbiące”. Twierdził, że wśród przywódców politycznych w londyńskim „grajdołku” korupcja jest tak powszechna, że zarzut ten „nawet nie potrzebuje uzasadnień”. Działaczom Rady Politycznej, którzy „byli i są na usługach różnych wywiadów międzynarodowych, ciągnęli i ciągną z tego korzyści materialne", odmawiał prawa do zabierania głosu w kwestii zjednoczenia emigracji. Nawiązując do nagłośnionej przez „zamkowych” polityków afery Bergu, podkreślił:

Sprawa niepodległości Polski i zachowania jej terytoriów nie może być miejscem dla szkolenia nieuków politycznych i terenem buszowania obcych agentów, gdyż koszta tego zawsze będzie płacił Naród Polski, to jest chłop, robotnik i pracownik umysłowy².

Protestując przeciwko decyzjom CKZ, Polowiec oświadczył, że nie ma zamiaru poddać się „rozprawom kapturowych sądów” i sam wystąpił z partii. W piśmie do władz PPS z 22 maja stwierdził:

Swym porozumieniem z faszyzmem polskim, przejściem na garnuszek wywiadów sami panowie wykluczyli się z szeregu Polskiej Partii Socjalistycznej i nie mają żadnego prawa do reprezentowania Polskiego Socjalizmu, który niewątpliwie się odrodzi. Pozostając nadal czynnym członkiem Polskiej Partii Socjalistycznej, aktywnym działaczem ruchu robotniczego, który obecnie w Polsce stanowi czołową awangardę oporu przeciw dyktaturze agentów nasłanych z Moskwy, proszę skreślić me nazwisko z ewidencji organizacji panów.

Przy okazji przypominał, że od początku przeciwny był współpracy socjalistów z przebywającymi na emigracji „elementami sanacyjno-endeckimi”, „grabarzami niepodległości Polski i sprawcami cierpień klasy robot-

${ }^{2}$ H. Polowiec, Prawda w oczy kole!, „Narodowiec” 1954, nr 93, s. 3 (przedruk w: H. Polowiec, Przeciw zdradzie socjalizmu i demokracji, Londyn 1954, s. 32-35). Na temat Rady Politycznej i sprawy Bergu zob.: A. Friszke, Życie polityczne emigracji, Warszawa 1999, s. 130-141 i 147-155. O nawiązaniu przez Radę Polityczną kontaktów z rządami państw zachodnich wspomina P. Machcewicz, Emigracja w polityce międzynarodowej, Warszawa 1999, s. 51-52. 
niczej”. Jako członek CKZ PPS już w końcu 1949 roku głosował przeciwko utworzeniu Rady Politycznej przez PPS oraz Stronnictwo Narodowe i Polski Ruch Wolnościowy „Niepodległość i Demokracja”. Opowiadał się natomiast za współpracą z ruchem ludowym³ ${ }^{3}$. W odpowiedzi CKZ PPS 24 maja 1954 roku stwierdził, że Polowiec „znalazł się poza szeregami Polskiej Partii Socjalistycznej"

Kim był niepokorny działacz? Henryk Polowiec urodził się 7 czerwca 1910 roku w Nowym Sączu. Już we wczesnej młodości związał się ruchem socjalistycznym. Działał w Towarzystwie Uniwersytetu Robotniczego, a w wieku osiemnastu lat wstapił do PPS. W 1932 roku został wybrany na sekretarza Podhalańskiego Okręgowego Komitetu Robotniczego PPS. Na tym stanowisku pozostawał do wybuchu II wojny światowej. Równocześnie był sekretarzem powiatowego komitetu PPS w Nowym Sączu, organizatorem Związków Zawodowych i sekretarzem oddziału Związku Małorolnych RP. Poznał wówczas Adama Ciołkosza, wybijającego się działacza PPS młodego pokolenia z Tarnowa. Zawodowo pracował jako ślusarz w warsztatach PKP w Nowym Sączu. We wrześniu 1939 roku dostał się do niewoli niemieckiej. Wojnę przeżył w obozie jenieckim w Essen ${ }^{5}$.

Po wyzwoleniu obozu przedostał się do Włoch. W marcu 1946 roku był współorganizatorem Komitetu PPS we Włoszech. Na początku 1947 roku wraz z II Korpusem Polskim przybył do Wielkiej Brytanii. Szybko stał się jednym z czołowych działaczy socjalistycznych na emigracji. Na zjeździe organizacyjnym PPS w Wielkiej Brytanii w marcu 1947 roku wszedł w skład Komitetu Głównego. Następnie pełnił funkcję sekretarza (1948-1949),

${ }^{3}$ Biblioteka Polska w Londynie [dalej: BPL], CKZ PPS, 1783/362, Pismo H. Polowca z 22 V 1954 r. do CKZ PPS (przedruk w: H. Polowiec, Przeciw zdradzie..., s. 9-19 i 22-24). Mimo krytycznego stanowiska, po utworzeniu Rady Politycznej w grudniu 1949 r., Polowiec został jednym z przedstawicieli socjalistów w tej Radzie, zob. A. Friszke, Adam Ciotkosz. Portret polskiego socjalisty, Warszawa 2011, s. 483; A. Siwik, Polska Partia Socjalistyczna na emigracji w latach 1945-1956, Kraków 1998, s. 69.

${ }^{4}$ Komunikat CKZ PPS, „Robotnik” 1954, nr 3, s. 5.

${ }^{5}$ Informacje biograficzne H. Polowiec zawarł w liście z 22 V 1954 r. do CKZ PPS [w:] BPL, CKZ PPS, 1783/362 (zob.: H. Polowiec, Przeciw zdradzie..., s. 17-18). Zob. też: Archiwum Instytutu Pamięci Narodowej [dalej: AIPN], 01136/656, Streszczenie materiałów ze sprawy ag. „Góral” z 31 III 1955 r. 
I wiceprzewodniczącego (1949-1951) i zastępcy przewodniczącego organizacji wielkobrytyjskiej PPS. Blisko współpracował wówczas z Ciołkoszem, który był przewodniczącym Komitetu Głównego PPS Wielkiej Brytanii. Na pierwszym zjeździe PPS w Pont á Lesse w maju 1948 roku. Polowiec został wybrany zastępcą sekretarza Centralnego Komitetu Zagranicznego, wszedł również w skład Rady Partyjnej. Na II zjeździe PPS w Lens w styczniu 1952 roku jako jedyny przedstawiciel wewnątrzpartyjnej opozycji ponownie został wybrany do CKZ oraz do Rady Centralnej ${ }^{6}$.

Współpracę socjalistów z narodowcami z nidowcami krytykowali również działacze sekcji paryskiej PPS na czele z Lucjanem Krawcem. W końcu 1951 roku Krawiec i Polowiec zamierzali wydać „W oparciu wyłącznie o fundusz składkowy” pierwszy numer czasopisma „Droga Wolności”. Zawiadamiając CKZ o swoim projekcie mieli nadzieję, że wła-

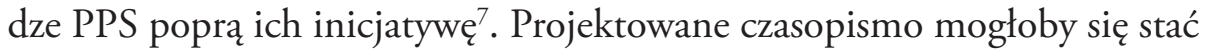
trybuną wewnątrzpartyjnej opozycji. W odpowiedzi Tomasz Arciszewski (przewodniczący CKZ PPS) oraz Franciszek Białas (sekretarz CKZ PPS) zawiadomili niepokornych działaczy, że partia „tylko z trudem utrzymuje dwa czasopisma” („Robotnik” i „Światło”). Chcąc zdławić rodzącą się w szeregach PPS opozycję, stwierdzili, że w tych warunkach nie widzą potrzeby wydawania nowego pisma. Zachęcając Krawca i Polowca do współpracy z istniejącymi już czasopismami socjalistycznymi, przywódcy PPS zakazali im równocześnie zamieszczania artykułów w „Drodze Wolności” lub w „podobnym piśmie”.

Jednak Krawiec i Polowiec nie ustępowali. W liście do Prezydium CKZ PPS protestowali przeciwko zakazowi współpracy z innymi czasopismami, nawet nie narodzonymi jeszcze. Twierdzili, że ,jest to stanowczo za daleko posunięta nieufność, nieusprawiedliwiona niczym, a więc obrażająca

${ }^{6}$ BPL, CKZ PPS, 1783/366-369, Materiały zjazdów PPS w Wielkiej Brytanii (1947-1950); A. Friszke, Adam Ciotkosz..., s. 382, 429-430, 437, 449-450; A. Siwik, op. cit., s. 82, 107, 185, 207, 210, 214, 216, 220.

7 Biblioteka Polska w Paryżu [dalej: BPP], Archiwum Lucjana Krawca [dalej: ALK], akc. 3270, Pismo L. Krawca i H. Polowca z 15 XI 1951 r. do CKZ PPS. Zob.: A. Siwik, op. cit., s. 68.

${ }^{8}$ BPP, ALK, akc. 3270, Pismo CKZ PPS do L. Krawca i H. Polowca z 23 XI $1951 \mathrm{r}$. 
nas"9. Zapowiadany numer nowego czasopisma ostatecznie nie ukazał się, natomiast zarząd sekcji paryskiej z okazji zbliżającego się II zjazdu PPS wydał jednodniówkę „Nasze Stanowisko”. Na jej łamach Polowiec alarmował:

Polska Partia Socjalistyczna znalazła się obecnie w ślepej uliczce. Kolejno, w ciągu dwóch lat, błędna koncepcja lub złe wykonanie gnały ją w sytuację bez wyjścia. [...] Nasi sojusznicy z Rady Politycznej, to element bardzo niepewny; w każdej chwili mogą się stać naszymi jawnymi wrogami, gdyż cichymi byli, są i będą. [...] Wyjście można znaleźć - pisał - ale należy ustalić kolejność zagadnień i ich rozwiązań. Trzeba sobie raz przy tym powiedzieć jedno: czy długo jeszcze będziemy się bawić w „ciuciubabkę" z sanacją, przemawiając doń „dialektycznie”: „P[anie] Zaleski, my pana nie uznajemy jako prezydenta, ale pan musi ustąicić...". Wiadomo p. Zaleski droczy się i mówi nie... Czas skończyć z tymi mamidłami sanacyjnymi i przystąpić do odbudowy obozu demokratycznego polskich partyj politycznych ${ }^{10}$.

Polowiec rozgoryczony podjazdowymi walkami uważał, że działacze wewnątrzpartyjnej opozycji nie mają po co jechać na II zjazd PPS na obczyźnie w styczniu 1952 roku do Lens:

Według mego obrachunku - pisał do Krawca - Zjazd mamy przegrany pomimo, że ci towarzysze, którzy próbowali ratować „klejnoty” legalizmu z rąk sanacji przegrali sprawę tak politycznie, jak taktycznie, [to] demagogią i oszczerstwami zakrzyczą nas. Więc co robić? ${ }^{11}$.

Opozycjoniści, choć ostatecznie pojechali do Lens, nie zdobyli szerszego poparcia. Zdecydowana większość delegatów na zjazd poparła dotychczasową linię CKZ. Przedstawiciele opozycji (Lucjan Krawiec, Leszek Florczyk, Bolesław Kruk czy Leszek Talko) przepadli w wyborach do naczelnych władz partii. Do Rady Centralnej i Centralnego Komitetu Zagranicznego PPS wszedł jedynie Henryk Polowiec ${ }^{12}$.

${ }^{9}$ Ibidem, Pismo L. Krawca i H. Polowca do Prezydium CKZ PPS z 10 XII 1951 r.

${ }^{10}$ Ibidem; H. Polowiec, O wtaściwa droge i program dziatania, „Nasze Stanowisko” 1951, s. 2-3.

${ }^{11}$ BPP, ALK, akc. 3266, List H. Polowca do L. Krawca z 9 XII 1951 r.

12 A. Siwik, op. cit., s. 103-107. 
We wrześniu 1952 roku opozycjoniści wydali pierwszy numer czasopisma „Równość”. Na łamach pisma Polowiec opowiadał się za utworzeniem nowej reprezentacji politycznej emigracji - Rady Jedności Narodowej. W jej skład miałyby wejść ugrupowania "demokratyczne” (przede wszystkim socjaliści), natomiast „sanacja”, „obóz faszystowski” i „reakcyjny” miały być z RJN wyeliminowane. Zadaniem „obozu demokratycznego” była walka o „wyzwolenie i uwolnienie kraju spod okupacji sowieckiej” oraz „niedopuszczenie do restauracji obozu wstecznictwa polskiego”. Krytykując politykę kierownictwa PPS (współpracę z endecja), podkreślił:

Socjaliści zaś muszą pamiętać, iż są socjalistami i mają budować w niedalekiej przyszłości w Polsce ustrój socjalistyczny ${ }^{13}$.

Występując z szeregów emigracyjnej PPS, Polowiec zarzucał swym wewnątrzpartyjnym adwersarzom, że „byli i są na utrzymaniu funduszów szpiegowskich” oraz wydzierżawili firmę PPS „pewnemu wywiadowi”. Chodziło mu o współpracę Rady Politycznej, w tym PPS, z wywiadem amerykańskim (Centralną Agencją Wywiadowczą - CIA). W liście do kierownictwa PPS podkreślił: „Zawsze czułem wstręt i niesmak do rzeczy i sprawek, mających posmak niemiły”. Dodał też: „Żyłem zawsze z pracy swych rąk, podczas gdy wielu członków CKZ pracą zarobkową się nie obciążało" ${ }^{\prime 4}$.

Oskarżając swoich politycznych przeciwników o zdradę i uzależnienie finansowe od zachodnich służb specjalnych, Polowiec sam kontaktował się z wywiadem... Polski Ludowej. Komunistyczne służby zainteresowały się niepokornym działaczem PPS w 1951 roku. Ze względu na wysoką pozycję w strukturach partii (zastępca sekretarza CKZ i wiceprzewodniczący Komitetu Głównego PPS w Wielkiej Brytanii) oraz „dojście” do wielu działaczy socjalistycznych Polowiec był potencjalnie cennym źródłem informacji. Spodziewano się, że przy jego pomocy wywiad zyska „możność wnikania we wszystkie machinacje WRN [PPS]”. Do „opracowania” kandydata

13 H. Polowiec, Rada Jedności Narodowej, „Równośc” 1952, nr 1, s. 6-9.

${ }^{14}$ BPL, CKZ PPS, 1783/362, Pismo H. Polowca z 22 V 1954 r. do CKZ PPS (zob.: H. Polowiec, Przeciw zdradzie..., s. 13). 
i ewentualnego werbunku zamierzano wykorzystać jego brata, Edwarda, mieszkającego w Nowym Sączu. Jak ustalono, Polowiec utrzymywał z nim kontakt korespondencyjny, przysyłał mu również paczki i pieniądze ${ }^{15}$.

Pod koniec marca 1952 roku Edward Polowiec, korzystając rzekomo z okazji, przekazał za pośrednictwem „Marynarza” ze statku „Jarosław Dąbrowski”, który pływał do Wielkiej Brytanii, list i paczkę do brata w Londynie. W rzeczywistości akcja została przygotowana przez wywiad. Kilka miesięcy później kontakt z „Góralem” (pseudonim Henryka Polowca) przeją „,Julek”, rzekomo znajomy „Marynarza”, w rzeczywistości kadrowy pracownik londyńskiej rezydentury wywiadu. Funkcjonariusz wywiadu pod pozorem drobnego handlu spotkał się z Polowcem 6 lipca 1952 roku, podając się za pracownika Polskiej Żeglugi Morskiej. Gdy parę dni później Polowiec niespodziewanie przyszedł do ambasady, natknął się na... „Julka”, który pełnił funkcję woźnego. Prawdopodobnie już wcześniej podejrzewał, że jego rozmówca w rzeczywistości był pracownikiem reżimowej placówki. „Góral”, wyraźnie zmieszany nieoczekiwanym spotkaniem, udawał, że nie poznał "Julka”. Spytał go tylko o adres konsulatu generalnego i wyszedt. Mimo zdekonspirowania "Julka” Polowiec nie zerwał z nim kontaktu. Do początku grudnia 1952 roku mieli się spotkać jeszcze pięć razy, załatwiając drobne interesy handlowe (kupno lekarstw i pończoch nylonowych) ${ }^{16}$.

Aby doprowadzić do zwerbowania Polowca, w grudniu 1952 roku z Warszawy do Londynu przyjechał oficer wywiadu „Czesław”. Wieczorem 10 grudnia "Julek" umówił się na kolejne spotkanie z Polowcem na stacji metra. Następnie udali się pieszo do pobliskiego baru, do którego wszedł również „Czesław”. Po kilku minutach na umówiony znak, gdy „Julek” wytarł nos chustką, „Czesław” dosiadł się do nich. Gdy podszedł do stolika, „Julek” rozpoznał w nim „znajomego” z kraju! Następnie wspólnie pili alkohol, a później przenieśli się do restauracji, gdzie zjedli kolację. W rozmowie z „Julkiem” i „Czesławem”, Polowiec podkreślał, że jest zdecydowanym przeciwnikiem politycznym sanacji i endecji. „W zasadzie nie szkalował”

15 AIPN, 01136/656, Notatka informacyjna z 14 VIII $1951 \mathrm{r}$.

${ }^{16}$ Ibidem, Streszczenie materiałów ze sprawy agenturalnej „Góral” z 31 III 1955 r.; ibidem, Raport dot. Henryka Polowca ps. „Góral” z 26 X 1956 r. 
również stosunków panujących w kraju. Gdy „Czesław” został sam na sam z Polowcem, oświadczył, że jest przedstawicielem władz Polski Ludowej i przyjechał specjalnie do Londynu, aby porozmawiać z nim ,jak przedstawiciel klasy robotniczej z robociarzem”. Dodał, że u wielu wysoko postawionych osób w kraju Polowiec cieszy się dużym zaufaniem. Jak wynika z dokumentów, działacz emigracyjnej PPS nie odrzucił propozycji współpracy. Obawiał się jednak prowokacji ze strony służb brytyjskich bądź polityków emigracyjnych. „Czesław” gwarantował mu, że „w wypadku jakiegoś nieszczęścia” w każdej chwili będzie mógł wrócić do kraju, gdzie do końca życia będzie miał zapewnione odpowiednie warunki materialne. Oficer wywiadu dodał: „nas nie interesują ani Anglicy, czy Anglia”. Rozumiem powiedział Polowiec: „emigracja”. Na pytanie o szczegóły „Czesław” powiedział mu:

interesuje nas działalność reakcyjnej emigracji, jej bandyckie poczynania w stosunku do Kraju, interesuje nas zatem sanacja z jej „rządem”, polskimi socjalistami i inne stronnictwa opanowane przez nią, interesuje nas Rada Polityczna - stronnictwa wchodzące w jej skład, a także i PPS.

Oficer wywiadu dodał, że w zamian za przekazywane informacje, Polowiec może liczyć „na zapewnienie [mu odpowiednich] warunków materialnych”. Następnie wyjął z portfela 50 funtów i wręczył Polowcowi. Ten wziął pieniądze bez słowa i schował do kieszeni płaszcza (wcześniej mówił, że „obecnie ma wyjątkowo fatalną sytuację materialną w domu”). Na zakończenie spotkania dopytywał się, czy może liczyć na podobne wynagrodzenie co miesiąc: „coś koło tego” - odpowiedział oficer wywiadu i dodał, że „na pomoc zawsze może liczyć”. Polowiec zdecydowanie odmówił pokwitowania odbioru pieniędzy, gdyż obawiał się prowokacji. W tej sytuacji funkcjonariusz nie nalegał ${ }^{17}$.

Do początku kwietnia 1953 roku „Czesław” jeszcze dziesięć razy miał się spotkać z „Góralem”. Polowiec udzielał mu przeważnie ustnych informacji (niechętnie sporządzał pisemne raporty), co przedłużało niepotrzebnie spotkania, zwiększając możliwość dekonspiracji. Przekazywane przez

17 Ibidem, Raport z 11 XII 1952 r. z przebiegu werbunku „Myśliwego” [H. Polowca]; ibidem, Uzupełnienie raportu z 11 XII 1952 r. dot. „Myśliwego”. 
"Górala” wiadomości miały „jedynie charakter informacyjny”. Choć nie stwierdzono, by Polowiec podawał fałszywe informacje, to ich poważnym mankamentem był brak wskazania źródła. Do ciekawszych należały wiadomości o przebiegu misji zjednoczeniowej gen. Kazimierza Sosnkowskiego. Donosiciel przekazał też ogólnikowy wykaz organizacji i osób zajmujących się problematyką wojskową na emigracji oraz notatki dotyczące sytuacji finansowej gen. Władysława Andersa czy struktury władz naczelnych Stronnictwa Narodowego. Większość z tych informacji była już jednak znana wywiadowi, co obniżało ich wartość. Mimo to Polowiec otrzymywał wysokie wynagrodzenie (50 funtów miesięcznie). W ciągu pierwszych miesięcy współpracy wypłacono mu ogółem 200 funtów plus 6 funtów za rzekome wydatki poniesione przy zdobywaniu informacji. Polowiec nigdy nie kwitował pobranych pieniędzy. Nie podpisał też formalnego zobowiązania o współpracy. Gdy w kwietniu 1953 roku „Góral” nie przyszedł na umówione spotkanie z „Czesławem”, na początku maja kontakt nawiązał z nim „Julek”. Polowiec usprawiedliwiał się, że jest rzekomo inwigilowany przez Anglików lub swoich przeciwników politycznych. Na kolejnym spotkaniu znów się jednak nie pojawił. „Julek” nawiązał z nim kontakt dopiero 11 stycznia 1954 roku. „Góral”, podobnie jak wcześniej, tłumaczył się, że jest obserwowany i 5 lutego znowu nie przyszedł na spotkanie ${ }^{18}$.

Przełożeni mieli zastrzeżenia do pracy „Czesława”. Zarzucano mu, że od samego początku nie przekazywał Polowcowi konkretnych zadań do wykonania i nie żądał od niego właściwych materiałów, zwłaszcza dotyczących emigracyjnej PPS:

„Góral” otrzymywał nastawienia zbyt ogólnikowe, co ułatwiało mu lawirowanie przy jego oporach w dawaniu materiałów w ogóle ${ }^{19}$.

Na polecenie Centrali 25 kwietnia 1954 roku „Julek” ponownie nawiązał kontakt z Polowcem. Ustalił z nim również sposób łączności na przyszłość. Sygnałem do wywołania emigracyjnego działacza na spotkanie miał

${ }_{18}$ Ibidem, Raport weryfikacyjny agenta ps. „Góral” z 24 VIII 1953 r.; ibidem, Raport dot. Henryka Polowca ps. „Góral” z 26 X 1956 r.

${ }^{19}$ Ibidem, Streszczenie materiałów ze sprawy agenturalnej „Góral” z 31 III 1955 r. 
być list „o treści koleżeńskiej” podpisany imieniem „Władysław”. Po opuszczeniu przez Polowca szeregów PPS wywiad miał nadzieję na wykorzystanie jego wrogiego stosunku do czołowych działaczy tego ugrupowania: Franciszka Białasa, Zygmunta Zaremby czy Adama Ciołkosza. Jako były członek CKZ Polowiec miał również wpływ na wewnątrzpartyjną opozycję w PPS (grupa „Równości”), z którą pozostawał w kontakcie. Planowano przeprowadzić zasadniczą rozmowę z Polowcem i doprowadzić do jego formalnego zwerbowania. Jak się wydawało, za takim scenariuszem przemawiało „wykluczenie [Polowca] z WRN [PPS] i wrogi stosunek do CKZ”, a także „trudności finansowe i chciwość na pieniądze” oraz „fakt brania od nas pieniędzy za dawanie materiałów, co można wykorzystać przy rozmowie w wypadku odmowy współpracy" ${ }^{20}$.

Polowiec nie był jednak skory do formalizowania współpracy z wywiadem. Prowadząc polityczną rozgrywkę z kierownictwem PPS, obawiał się prowokacji i w rezultacie przerwał kontakty z tajnymi służbami. Jesienią 1954 roku nawiązał natomiast współpracę z „Tygodnikiem”. Pismo wydawane i redagowane przez Jana Matłachowskiego wspierało początkowo „zamek”, szybko ewoluowało jednak w kierunku rewizji „niezłomnej” postawy emigracji na pozycje „prokrajowe”. Zaledwie kilka miesięcy wcześniej Polowiec, jako niezłomny przeciwnik uznania Zaleskiego za prezydenta, protestował na posiedzeniu CKZ przeciw „taktycznym łamańcom” kierownictwa PPS, które poparło akcję scaleniową gen. Sosnkowskiego i złożyło podpis pod Aktem Zjednoczenia ${ }^{21}$. Swym oponentom w szeregach PPS zarzucał niekonsekwencję, wkrótce jednak sam zaczął publikować na łamach „zamkowego” pisma.

Dla Polowca „Tygodnik” był taktycznym sojusznikiem w jego wojnie z władzami PPS. Z drugiej strony, w otoczeniu prezydenta Zaleskiego żarliwe oskarżenia Polowca pod adresem rywali z obozu „zjednoczenia” uznano za politycznie użyteczne, nawet jeśli ich autor jeszcze niedawno równie żarliwie zwalczał „sanację” na emigracji. Na łamach „Tygodnika” Polowiec wyciszył niedawne ataki na „sanacje”, natomiast politykom z obozu „zjed-

\footnotetext{
${ }^{20}$ Ibidem.

${ }^{21}$ H. Polowiec, Przeciw zdradzie..., s. 19-22. Zob. też: A. Friszke, Życie polityczne..., s. 197-198.
} 
noczenia” wytykał prywatę oraz finansowe uzależnienie od Amerykanów. Podkreślił, że

w interesie Polski leży, abyśmy przepędzili różnych stypendystów, różnych „Free Europe”, którzy reprezentują nie Polski punkt widzenia w polityce. To, że kilku lub kilkudziesięciu darmozjadów dolarowiczów posiada łatwe środki do życia sprawie polskiej pożytku nie przynosi. Czas najwyższy, abyśmy się pozbyli tych strupów i wrzodów, które obsiadły polską niepodległościową emigrację i zatruwają swym odorem polski patriotyzm.

Przy okazji piętnował cynizm i obłudę polityki amerykańskiej oraz instrumentalne traktowanie przez Waszyngton sprawy polskiej:

W okresie kampanii wyborczych w Stanach Zjednoczonych można usłyszeć wiele obietnic dotyczących niepodległości Polski, po czym po wyborach następuje cisza i dopiero przy zaostrzaniu się zimnej wojny wyciągana jest sprawa Polski z lamusa, ale to tylko po to, aby dokuczyć Rosji sowieckiej ${ }^{22}$.

Podobnie jak „zamkowi” politycy, Polowiec przypominał, że „polityka niepodległościowa polska musi być oparta wyłącznie na polskim groszu, skromnym ale polskim”. Konsekwentnie przekonywał, że

Stany Zjednoczone prowadzą politykę walki z komunizmem jako niebezpiecznym ruchem społecznym, a nie politykę jakiegoś wyzwalania narodów ujarzmionych przez Rosję sowiecką.

Akcję „balonową”, prowadzoną przez Komitet Wolnej Europy, uważał za prowokację, gdyż „komuniści tylko czyhają, aby przeprowadzić krwawą rozprawę z elementem przeciwnym reżymowi komunistycznemu”. Zamiast akcji ulotkowej - twierdził -

Amerykanie jeśli rzeczywiście chcą pomóc, to niech lepiej obrzucą Polskę paczkami żywnościowymi, z ubraniami i lekarstwami ${ }^{23}$.

${ }^{22}$ H. Polowiec, Polityka polska czy amerykańska, „Tygodnik” 1955, nr 2, s. 2.

${ }^{23}$ Idem, To jest prowokacja, „Tygodnik” 1955, nr 12, s. 3. Zob. też: idem, H. Polowiec o polityce zagranicznej, „Tygodnik” 1955, nr 44, s. 3. 
Kilka miesięcy później, podważając zaufanie do polityki Białego Domu, powtarzał:

\begin{abstract}
i dzisiaj nie możemy mieć zaufania do polityki amerykańskiej odnośnie sprawy polskiej. Po prostu sprawa polska podnoszona jest jako slogan wyborczy, aby później po wyborach poszła do kosza i przy następnych wyborach [została] odgrzana jako kotlet ${ }^{24}$.
\end{abstract}

Antyamerykańskie nastroje od dawna były obecne w otoczeniu prezydenta Zaleskiego. W artykułach drukowanych w „Tygodniku” Polowiec przede wszystkim zwalczał jednak kierownictwo PPS oraz demaskował przywódców emigracyjnych. Wyrażając zadowolenie z utworzenia przez grupę „idealistów socjalistów” frakcji opozycyjnej, która

próbuje ratować przyszłość polskiego socjalizmu przed „koncesjonowanym" kierownictwem z tak zw. Centralnego Komitetu Zagranicznego PPS i „Delegacji Zagranicznej”,

zarzucał jednak opozycjonistom naiwną wiarę $\mathrm{w}$ samooczyszczenie się kierownictwa PPS. Wątpił, aby w łonie emigracyjnej PPS samoczynnie dokonała się „rewolucja odrodzenia, sprowadzająca ruch socjalistyczny z bezdroża zdrady i jednościowego zakłamania na szlak demokracji i socjalizmu”. Według Polowca, grupa „Równości”, nie posiadając w swym gronie członków władz centralnych PPS, nie będzie miała żadnego bezpośredniego wpływu na podejmowane uchwały, a „apelowanie do sumienia panów z CKZ PPS wyglądałoby zaś na wielką naiwność”. Namawiał opozycjonistów do wyjścia z PPS i stworzenia od podstaw własnej organizacji, aby w ten sposób wyeliminować z ruchu socjalistycznego „wszelkie agentury i pachołków polskiej reakcji społecznej"25.

Jesienią 1954 roku wewnątrzpartyjna opozycja wydała drugi numer „Równości”. Skłoniło to kierownictwo PPS do zdecydowanego działania. Na posiedzeniu plenarnym 29 stycznia 1955 roku CKZ PPS wydalił z szeregów partii Lucjana Krawca. W odpowiedzi pozostali przedstawiciele we-

\footnotetext{
${ }^{24}$ Ibidem.

${ }^{25}$ Idem, PPS bez demokracji, „Tygodnik” 1955, nr 8, s. 3-4.
} 
wnątrzpartyjnej opozycji, zawieszeni w prawach członków, solidaryzując się z Krawcem, wystąpili z szeregów PPS. Rozłam w ruchu socjalistycznym na emigracji stał się faktem. Kilka miesięcy później, 26 czerwca 1955 roku, secesjoniści utworzyli własne ugrupowanie: Polską Partię SocjalnoDemokratyczną ${ }^{26}$.

Polowiec nie przystąpił jednak do nowej partii, choć politycznie sympatyzował z secesjonistami. Na łamach „Tygodnika” apelował jednak do organizatorów PPS-D o większą aktywność:

muszą rozwinąć szerszą działalność, ruszyć w teren, rozpocząć akcję wydawniczą, zgromadzeniową i właściwie ustawić się do zagadnień emigracyjnych.

Zarzucał im, że ostatni numer „Równości” ukazał się przed ośmioma miesiącami. Obawiał się, że twórcy nowego ugrupowania mogą

przez brak organizacyjnej sprawności i sprężystości działania doprowadzić do zniweczenia zdrowej inicjatywy odrodzenia ruchu socjalistycznego, tak żywiołowo popartej przez doły socjalistyczne. A co najgorsze, mogliby w wypadku niepowodzenia narazić się na zarzut, iż współdziałali z mocodawcami p. Białasa, którzy opiekując się jego grupą starają się rozładować nastroje opozycyjne dołów socjalistycznych. [...] Byłoby klęską dla socjalizmu i demokracji - podkreślił Polowiec - jeśli akcja PPS-D nie powiodła by się $e^{27}$.

W prywatnym liście do Krawca z 20 sierpnia 1955 roku Polowiec zarzucał działaczom grupy paryskiej brak zdecydowania, organizacyjny niedowład czy wręcz działanie na korzyść władz PPS:

Jak się mówi „A”, to potem musi się powiedzieć „B”. Jeśli się występuje z PPS i zapowiada się odrodzenie PPS, to musi się działać, nikt jeszcze $\mathrm{w}$ czterech ścianach pokoju nie miał racji.

${ }^{26}$ Komunikat CKZ PPS, „Robotnik” 1955, nr 2, s. 1. Zob. też: Deklaracja grupy PPS, „Jutro Polski” 1955, nr 5/6, s. 8; A. Siwik, op. cit., s. 137-138.

${ }^{27}$ H. Polowiec, PPS w rozsypce, „Tygodnik” 1955, nr 34, s. 3-4. 
Skłócony z niektórymi działaczami PPS-D z Wielkiej Brytanii, nie zamierzał przystępować do nowego ugrupowania ${ }^{28}$.

W przededniu III zjazdu PPS na obczyźnie, zapowiadanego na 25 i 26 czerwca 1955 roku w Calais, Polowiec opublikował list otwarty do członków PPS. W broszurce pod symptomatycznym tytułem Dzieje Grzechu CKZ PPS skrytykował całą partyjną „górę” („bankrutów moralno-politycznych"). Po raz kolejny oskarżył kierownictwo PPS o zdradę partii oraz ideałów socjalizmu i demokracji dla własnych „brudnych interesów”. Odwołując się do „szczerych socjalistów”, którzy pozostali jeszcze w szeregach PPS, przypominał „najważniejsze przestępstwa i zdrady w stosunku do idei socjalistycznej”, których na przestrzeni ostatnich lat dopuścili się przywódcy partii. Władze PPS obwiniał o rozbicie ruchu socjalistycznego na emigracji, współpracę z sanacją, „faszystowskim odłamem” Stronnictwa Narodowego i ,juntą generalską". Członkom CKZ zarzucał

demoralizowanie organizacji i łamanie charakterów działaczy partyjnych przez korupcję lub represje (pozbawianie nieuległych towarzyszy pracy)

oraz

łamanie zasad demokratycznych w życiu wewnętrznym partii przez cenzurę polityczną, kneblowanie ust niezależnie myślącym socjalistom, zawieszanie i wyrzucanie z partii nieuległych CKZ-towej zdradzie towarzyszy, zaoczne wyroki, oszczerstwa i denuncjacje, stosowane wobec tych, którzy mają odwagę demaskować szkodników Ruchu Robotniczego.

Polowiec apelował do członków PPS, by się zastanowili,

czy pozostając w szeregach takiej PPS, w takim towarzystwie, nie przykładają ręki do grzebania sprawy socjalizmu, demokracji i niepodległości Polski ${ }^{29}$.

${ }^{28}$ BPP, ALK, akc. 3275, List H. Polowca do L. Krawca z 20 VIII 1955 r. Grupa londyńska wcale nie zamierzała zresztą wciągać Polowca do działalności organizacyjnej, zob. BPP, ALK, akc. 3265, List W. Goldmana do L. Krawca z 14 III 1955 r.

${ }^{29}$ H. Polowiec, Dzieje Grzechu CKZ PPS. List otwarty do członków PPS na obczyźnie, Londyn 1956. Broszurę reklamowało „Jutro Polski” zob.: Rozktad CKZ PPS, „Jutro Polski” 1955, nr 12, s. $1,3$. 
Choć broszura nie wywołała fermentu wśród delegatów na zjazd, Polowiec nie ustawał w atakach na kierownictwo PPS. Jak mantra brzmiały jego oskarżenia pod adresem kierownictwa PPS o doprowadzenie do rozbicia i rozkładu partii.

$\mathrm{Na}$ początku października 1955 roku, po półtorarocznej przerwie, wywiad PRL ponownie nawiązał kontakt $\mathrm{z}$ Polowcem. W tym celu z Warszawy do Londynu przyjechał niejaki Nowak. Spotkali się jeszcze dwukrotnie, ostatni raz 3 grudnia. Już podczas pierwszej rozmowy „Góral” demonstrował niechęć do współpracy. Skarżył się, że poprzedni łącznik źle z nim pracował. Twierdził też, że próbował go zwerbować wywiad amerykański, że był szantażowany przez ludzi z „zamku” oraz „dwójkę" Andersa. Nie podał jednak żadnych szczegółów. Nie dowierzał też Nowakowi, że jest przedstawicielem Centrali. Umówił się z nim jednak na następne spotkanie, na które nie przyszedł. Gdy Nowak zjawił się w jego domu, Polowiec zażądał od niego przedstawienia dowodów, że jest pracownikiem MSW. Egzaminował również oficera wywiadu z marksizmu. Ostatecznie zgodził się na dalszą współpracę pod warunkiem wypłacenia mu astronomicznej kwoty - 900 funtów (50 funtów miesięcznie tytułem wynagrodzenia za okres przerwy w kontaktach). Oficer wywiadu obiecał, że przedstawi sprawę wynagrodzenia do decyzji Centrali. Chcąc zainteresować tajne służby, powiedział, że Białas zajmuje się wywiadem na kraj kanałami przez Szwecję. Na kolejnym spotkaniu, 3 grudnia, Nowak tłumaczył Polowcowi, że jego żądania finansowe były zbyt wygórowane. „Góral” postawił jednak sprawę jasno: „płacimy, albo dajemy mu spokój”. Gdy Nowak próbował mu wręczyć 50 funtów, nie chciał przyjąć pieniędzy (oczekiwał więcej). Jednak pod koniec spotkania upomniał się o oferowaną mu wcześniej sumę ${ }^{30}$.

Do kolejnej rozmowy z Polowcem doszło 25 lutego 1956 roku. Oprócz Nowaka w spotkaniu udział wziął drugi oficer wywiadu - Fajda. "Góral” nie upierał się już przy żądaniu wypłaty 900 funtów. Zadowolił się 150 funtami, które wręczył mu Fajda. Nie pokwitował jednak odbioru pieniędzy. Zgodził się również, że w przyszłości jego wynagrodzenie zależeć będzie od wartości przekazywanych przez niego materiałów. Fajda spotkał się z Polowcem jeszcze trzy razy. Na żądanie wywiadu „Góral” zobowiązał

${ }^{30}$ AIPN, 01136/656, Raport dot. Henryka Polowca ps. „Góral” z 26 X 1956 r. 
się napisać broszurę kompromitującą kierownictwo PPS. Przed opublikowaniem miał ją przedstawić do wglądu. Oficer wywiadu dostarczył mu też kilka książek wydanych w kraju, które Polowiec chciał wykorzystać przy pisaniu broszury. „Góral” ociągał się z opracowaniem broszury i ostatecznie nie przedstawił jej do wglądu, tłumacząc się trudnościami technicznymi. Zapowiadał też napisanie „poważnej pracy” kompromitującej Andersa, sanację i Stronnictwo Narodowe. Na spotkaniu 30 czerwca 1956 roku Fajda wręczył informatorowi 30 funtów w kopercie. Polowiec schował pieniądze do kieszeni. Gdy pod koniec spotkania dowiedział się, że to „tylko” 30 funtów, zwrócił pieniądze, twierdząc, że to za mało i nie zgodził się na umówienie następnego spotkania. Nie chcąc jednak definitywnie zrywać kontaktu, stwierdził: „Jeśli panowie zechcą się spotkać ze mną, to proszę przyjść do mnie do domu w każdą sobotę do południa"31.

Choć Polowiec nie przekazał żadnych istotnych informacji, to wyciągnął od wywiadu aż 464 funty. Analizując współpracę z „Góralem”, funkcjonariusze wywiadu stwierdzili wprost: „Dawano mu pieniądze za nic, co w pewnym stopniu demoralizowało go". Początkowo informator twierdził, że współpraca z komunistycznym wywiadem nie była zgodna z jego sumieniem wobec partii (PPS). Później usprawiedliwiał swoją niechęć do współpracy brakiem zaufania do kontaktujących się z nim funkcjonariuszy, inwigilacją i obawą przed dekonspiracją. Obawiał się też, że może być szantażowany, dlatego nie kwitował otrzymywanych pieniędzy. Nie odmówił jednak stanowczo współpracy. Zgadzał się na następne spotkania, przyjmował zadania, lecz ich nie wykonywał. Funkcjonariusze wywiadu tłumaczyli to tym, że „jest on chytry na pieniądze, lubi wypić, liczył, że może od nas otrzymać pewną ilość funtów”. Mimo krytycznej oceny "Górala”, w Centrali MSW uznano, że nie należy zrywać z nim kontaktu i rezygnować z prób pozyskania go do współpracy, gdyż na terenie Wielkiej Brytanii wywiad nie posiadał w ogóle agentury „w środowisku WRNowskim”. Planowano przeprowadzić z Polowcem „decydującą rozmowę”. Funkcjonariusz wywiadu, wskazując na „nieszczery i niejasny” stosunek „Górala”, miał go nakłonić do współpracy „na wysuniętych przez nas warunkach”, a w razie odmowy „rozwiążemy z nim nasz stosunek”. Ponadto

${ }^{31}$ Ibidem. 
bazując na uczuciach patriotycznych, pracownik krytycznie oceni jego dotychczasową pomoc dla Kraju, jako niedostateczną, wskazując na momenty nieszczerości, nieufności i nieuczciwości.

Jeżeli Polowiec zgodziłby się na dalszą współpracę, oficer wywiadu miał głębiej rozpoznać jego możliwości oraz aktualne kontakty z działaczami emigracyjnej PPS i innych ugrupowań. Należało również wyjaśnić sprawę jego rzekomego werbunku przez wywiad amerykański: kto, kiedy, w jakich okolicznościach i w jakiej formie próbował go werbować oraz o kogo pytano i czego od niego żądano ${ }^{32}$.

$\mathrm{Na}$ podstawie zachowanej dokumentacji nie sposób stwierdzić, czy do planowanej rozmowy doszło. Polowiec nie zerwał jednak kontaktów z wywiadem komunistycznym. Na łamach „Tygodnika” kontynuował również swoją kampanię przeciwko kierownictwu PPS. Demaskował też postępowanie przywódców emigracji oraz politykę Stanów Zjednoczonych. Konsekwentnie podważał wiarę rodaków w kraju i na emigracji w Zachód:

Nasi byli alianci - podkreślał na początku 1956 r. - uznali narzucony narodowi polskiemu rząd komunistyczny i z tym faktem należy się liczyć. Wszelka akcja, jaka jest prowadzona na kraje poza żelazną kurtyną, jest akcją prywatną, antykomunistyczną i nie ma nic wspólnego z akcją wyzwoleńczą. Staramy się trzymać Zachodu za połę surduta, lecz jesteśmy stale odtrącani i kopani.

Podważając sens akcji niepodległościowej wychodźstwa na arenie międzynarodowej, podważał rację bytu emigracji politycznej. Wytykał też emigracji brak programu na odcinku polityki zagranicznej, „który jest najważniejszy". Nie przebierając w słowach, zarzucał emigracyjnym politykom („utrzymankom «Free Europe»”) sprzedajność i uzależnienie od Waszyngtonu:

Sprawa niepodległości i nasze działanie na terenie międzynarodowym twierdził - nie może być monopolem dla zbankrutowanej kliki politycznej wysługującej się dolarowcom ze szkodą dla Kraju.

${ }^{32}$ Ibidem. 
Winą za represje w kraju w minionych latach obarczał działaczy emigracyjnej Rady Politycznej, którzy dali pretekst komunistom do aresztowań! W tej sytuacji nie dziwi już jego sugestia, że nie ma większej różnicy między demokracją ludową w krajach komunistycznych a demokracją na Zachodzie:

Tam biorą za mordę i tutaj chcieliby to samo stosować... Gdzież ta wyższość nad dyktaturą komunistyczną 33 .

W jednym z kolejnych numerów „Tygodnika”, Polowiec, kreując się na obrońcę interesów Polski, krytykował proniemiecką i antypolską politykę Białego Domu. Wskazując na powiązania przemysłu amerykańskiego i niemieckiego, zaznaczył:

naprawdę tylko „dziwni” Polacy mogą łudzić emigrację, iż możemy spodziewać się pomocy od Stanów Zjednoczonych w obronie granic na Odrze i Nysie ${ }^{34}$.

Przekonywał też, że reedukacja i demokratyzacja Niemców to fik$\mathrm{cja}^{35}$. Antyamerykańskie i antyniemieckie wątki zdominowały publicystykę Polowca.

W przededniu majowej wizyty Nikity Chruszczowa i Nikołaja Bułganina w Londynie w 1956 roku skrytykował projekt zorganizowania przez emigrację demonstracji protestacyjnej:

Hałas, jaki jest robiony z powodu wizyty przedstawicieli rządu sowieckiego, przez emigracyjnych prowodyrów będących na utrzymaniu Wolnej Europy, właściwie nie jest antykomunistyczny... i czuć go prowokacją.

Jedynym skutkiem demonstracji - twierdził przewrotnie Polowiec będzie wzrost antypatii do emigracji wśród Anglików, a „zysk z takiego

${ }^{33}$ H. Polowiec, Gtos socjalisty $w$ trosce o rodaków w Kraju, „Tygodnik” 1956, nr 2, s. 4.

${ }^{34}$ Idem, Bywalcy lubia ptywać, „Tygodnik” 1956, nr 6, s. 3. Zob. też: idem, Zbratanie finansjery, „Tygodnik” 1956, nr 14, s. 4.

35 Idem, Wilkotaki, „Tygodnik” 1956, nr 18, s. 4. 
nastroju odniosą jedynie rządy za żelazną kurtyną..." "36. Wniosek, jaki się nasuwał po lekturze artykułu Polowca brzmiał: emigracja swoimi nieprzemyślanymi akcjami działa na korzyść komunistów w Polsce!

Po Październiku 1956 roku, Polowiec z aprobatą pisał o Władysławie Gomułce. Chwalił go za zmysł polityczny oraz wyczucie ogromu odpowiedzialności za losy narodu i państwa. Jednocześnie pokpiwał z Ciołkosza, który z emigracji nawoływał do stworzenia rządu robotniczo-chłopskiego

przy pomocy: totalistów, byłych żyletkarzy z ONR i byłych dzierżymordów z Obozu Zjednoczenia Narodowego, z którymi na wspólnej ławie zasiada w TRJN.

Nawiązując do „zjednoczenia” ruchu robotniczego w kraju, argumentował, że polskich robotników „nie stać na dwie zwalczające się partie polityczne, choćby określały się mianem socjalistycznym”. Wobec zmian dokonujących się w kraju, zapowiadał koniec emigracji politycznej: „przemiany krajowe - twierdził - w sensie politycznym wykończyły politycznie emigrację" 37 .

W przededniu IV zjazdu PPS na obczyźnie, zapowiedzianego na koniec września 1957 roku, Polowiec po raz kolejny zarzucił swoim byłym partyjnym towarzyszom zdradę socjalizmu i demokracji. Uważając się za ideowego socjalistę, podkreślił, że „socjalizm buduje się w Polsce w ciężkich warunkach, ale nie na emigracji”" ${ }^{38}$. Sam nie wybierał się jednak do kraju.

W 1957 roku Polowiec opublikował trzecią broszurę, w której oskarżył emigrację o różne afery finansowe. Sensacyjny tytuł (Co emigracja przemilcza) miał oddziaływać na wyobraźnię i wzbudzać zainteresowanie potencjalnego czytelnika. Za cel Polowiec postawił sobie

opisać grabieże funduszów państwowych, społecznych i dzieje różnych tworków emigracyjnych, aby przyszły historyk emigracyjny mógł łatwiej znaleźć klucz do niepowodzeń politycznych emigracji, a czytelnik miał

36 Idem, H. Polowiec przeciw projektowanej demonstracji, „Tygodnik” 1956, nr 11, s. 4 .

37 Idem, „Lekarzu ulecz wpierw siebie”, „Tygodnik” 1957, nr 1, s. 3.

38 Idem, „Zjazd PPS”, „Tygodnik” 1957, nr 30, s. 3. 
obiektywny sąd o przywódcach politycznych, którzy doprowadzili do zaprzepaszczenia sprawy polskiej na Zachodzie, a w Kraju zohydzili opinię naszej emigracji (s. 2).

Propagandowy charakter broszury sprawił, że jej treść rozmijała się z deklaracją autora. „Zbankrutowanym politykom”, uważającym się „za dziedzicznych, niezastąpionych przywódców emigracji i Narodu Polskiego w Kraju”, Polowiec zarzucał przywłaszczenie publicznych pieniędzy pod pozorem „roboty krajowej” (s. 9-10). Według niego, przywódcy emigracji gromadnie przeszli na utrzymanie zagranicznych (zachodnich) wywiadów. Dowodem „zgnilizny moralnej” - przekonywał Polowiec - była afera Bergu. Podobnych sfer - stwierdził - „było więcej”. Głównym powodem przejścia „na dolarowy żołd” miały być nie względy ideowe, ale „zdobycie materialnych środków do wygodnego życia”.

Jest nie do pomyślenia - pisał z oburzeniem Polowiec - aby zajęcie informatora i organizatora siatki szpiegowskiej było windowane do godności działania „niepodległościowego” (s. 18).

Dodał, że „żuliki” z Rady Politycznej naciągnąć mieli Amerykanów na ponad milion dolarów (s. 20). Przedstawiając „rodowód” Polskiego Ruchu Wolnościowego „Niepodległość i Demokracja”, podkreślił: „NiD nie jest organizacją demokratyczną; jest mafią emigracyjną. Gdziekolwiek się pojawią nidowcy, tam na pewno są pieniądze" (s. 24). Jednak głównym organizatorem „afery szpiegowskiej” miało być Stronnictwo Narodowe: „wylęgarnia polskiego faszyzmu, szowinizmu i wstecznictwa społecznego” (s. 24), które „obok nawyków do łatwego grosza posiada najwięcej zasług w szerzeniu demoralizacji i korupcji wśród swych członków” (s. 26). Krytykując współpracę kierownictwa PPS z „reakcją społeczno-polityczną” na emigracji, równocześnie z aprobatą pisał o „zjednoczeniu” PPS z PPR w kraju, czego „wymagała Jedność Klasy Robotniczej” (s. 30). Negując zaś sens akcji politycznej wychodźstwa na arenie międzynarodowej, stwierdził, że poza pożyteczną wysyłką paczek z ubraniami i lekarstwami do kraju, emigracja „nic więcej nie wniosła”. Jedynym sojusznikiem, chroniącym Polskę przed „bardzo realnym niebezpieczeństwem odwetowym płynącym z Niemiec Zachodnich”, była według Polowca „Rosja Sowiecka” (s. 39). Rozwiewając 
nadzieje na pomoc z Zachodu, podkreślił: „Z punktu widzenia interesów polskich nie wolno się łudzić na jakąkolwiek pomoc ze strony państw zachodnich i Stanów Zjednoczonych". Zupełnie kuriozalnie brzmiała teza Polowca, że to emigracja swoimi działaniami poniekąd zmuszała komunistyczny aparat bezpieczeństwa w kraju do stosowania represji:

Terror policyjny, jaki miał miejsce w Polsce do rewolucji „Październikowej” 1956 r. był owocem nie tylko linii Stalina, lecz również niektórych ośrodków emigracyjnych. Podświadomie przez zorganizowanie podziemia tworzyły one atmosferę do istnienia tegoż terroru (s. 43).

W przekonaniu Polowca rola emigracji politycznej wobec wydarzeń w kraju w 1956 roku skończyła się. Apelował do emigrantów, aby w nowej sytuacji skończyli z jałowymi sporami i przerzucili się na działalność gospodarczą: „Obowiązkiem emigracji - podkreślił - jest utrzymać łączność z Krajem, gospodarczą i kulturalną" ${ }^{39}$. Przekształcenie emigracji w neutralną politycznie grupę polonijną, a następnie pozyskanie jej dla „pozytywnej” współpracy z krajem stało się głównym celem działań władz PRL wobec wychodźstwa.

Jeszcze w 1957 roku Polowiec zaczął publikować w „Naszym Znaku”. Ukazujący się w Szwecji miesięcznik był początkowo organem Polskiego Stronnictwa Ludowego na emigracji. W końcu 1956 roku jego założyciel i redaktor naczelny, Waldemar Sobczyk, został zwerbowany przez wywiad PRL. W następnych latach „Nasz Znak” był regularnie dotowany przez tajne służby. Na łamach miesięcznika Polowiec był etatowym krytykiem emigracyjnych socjalistów. Posługując się marksistowską retoryką, opowiadał się za sojuszem klasy robotniczej z chłopstwem i inteligencją pracującą. Kierownictwu PPS zarzucał zaś „szereg kardynalnych błędów w prowadzeniu na emigracji polityki socjalistycznej" ${ }^{40}$. Zafascynowany liberalizacją systemu komunistycznego w kraju po 1956 roku, pisał:

39 Idem, Co emigracja przemilcza, Londyn 1957. Numery stron, na których znajdują się przytoczone fragmenty, podano w nawiasie, bezpośrednio po cytacie.

40 Idem, Przed IV zjazdem PPS na obczyźnie, „Nasz Znak” 1957, nr 9 (64), s. 18-19. Zob. też: idem, Nowa spótka w PPS, „Nasz Znak” 1957, nr 10/11 (65/66), s. 28-30; idem, Cztery zjazdy PPS na emigracji, „Nasz Znak” 1958, nr 4 (71), s. 18-20. Szerzej na temat 
Po rewolucji październikowej w Polsce, w życiu politycznym i gospodarczym zaszły głębokie zmiany, które w skutkach wykończyły sens istnienia politycznej emigracji polskiej. Obecnie „wielki niemowa” Kraj przemawia sam za siebie ${ }^{41}$.

W ocenie wywiadu PRL, w końcu lat pięćdziesiątych Polowiec popadł $\mathrm{w}$ manię prześladowczą. Twierdził, że jest inwigilowany przez różne wywiady, Anglików, emigrację, że ktoś czyha na jego życie, że jest ciągle śledzony. W marcu 1960 roku zgłosił się w tej sprawie w Konsulacie Generalnym PRL w Londynie z prośbą o pomoc i opiekę przed prześladowcami. Zdesperowany, w rozmowie z „Rochem”, pracownikiem konsulatu (w rzeczywistości oficerem wywiadu), ujawnił fakt współpracy z tajnymi służbami. W tej sytuacji postanowiono repatriować „Górala” do kraju. Pobrał on nawet kwestionariusze paszportowe. Sprawa ciągnęła się kolejny rok. Ostatecznie Polowiec odmówił wyjazdu do Polski, tłumacząc to względami rodzinnymi (jego żona była Angielka) ${ }^{42}$.

We wrześniu 1963 roku „Góral” został ostatecznie „wyeliminowany z sieci agenturalnej” przez wywiad PRL ,ze względu na brak dotarcia do interesujących nas środowisk i objawy choroby psychicznej” ${ }^{43}$.

Henryk Polowiec zmarł 8 kwietnia 1982 roku w Londynie ${ }^{44}$.

„Naszego Znaku” zob.: K. Tarka, Waldemar Sobczyk i „Nasz Znak” - dywersja w ruchu ludowym na emigracji, „Pamięć i Sprawiedliwość” 2011, nr 2 (18), s. 321-362.

${ }^{41}$ Idem, Oszustwem nie zbuduje socjalizmu, „Nasz Znak” 1957, nr 7/8 (62/63), s. $15-18$.

42 AIPN, 01136/656, Notatka końcowa dot. H. Polowca ps. Góral z 11 IX 1963 r.

43 Ibidem, Postanowienie z 10 IX 1963 r. o zakończeniu rozpracowania operacyjnego krypt. „Góral” i przekazaniu sprawy do archiwum Departamentu I.

44 Zgony i nabożeństwa żatobne, "Dziennik Polski i Dziennik Żołnierza” 1982, nr 104 , s. 4. 


\section{Political meanderings of emigrant socialist. Contacts of Henryk Polowiec with the Polish People's Republic (PRL) intelligence in years 1952-1963}

(Summary)

H. Polowiec connected with socialist movement in the 30s. of the XX century. After World War II he ended up in emigration in Great Britain, where he became one of the leading activists of the Polish Socialist Party (PPS). In 1954, because of criticism of the political line of the PPS he was suspended in the rights of party member. In response, he accused the authorities of PPS, that they became the agency of western intelligences, and withdraw from the party. He was also criticizing socialists for political cooperation with National Democrats in emigration. From 1952 to 1963 (with interruptions) he was also secretly contacting with PRL intelligence. For submitted orally information he received remuneration. In issued in London magazine "Tygodnik" and in political brochures he was criticizing leadership of the PPS. Considering himself as conceptual socialist he accused his former party companions of betrayal of socialism and democracy. After October 1956, fascinated by liberalization of the communist regime, he wrote with approval about W. Gomułka. In PRL intelligence estimation, Polowiec fell into persecution mania. As a result, in 1963 the communist secret service ended cooperation with him.

Krzysztof Tarka

Instytut Historii, Uniwersytet Opolski e-mail: krzysztof-tarka@wp.pl 
